\title{
Dyglosja w historii greckiego języka prawa
}

\section{Diglossia in history of legal Greek language}

\author{
Karolina Gortych \\ Instytut Językoznawstwa, Uniwersytet im. Adama Mickiewicza \\ al. Niepodległości 4, 61-874 Poznań \\ kmmgortych@gmail.com
}

\begin{abstract}
A diglossia is a typical phenomen for Greek language from the beginning of existence the modern Greek state (1830). The Greeks spoke "two languages" which were attributed to definited social activities. Language of Law was very archaic type of language which lied on the idea of purification of the language which exactly was idea of "katharevousa" - an artificial language system. This situation lasted till the year 1976. In the same time, simultaneously a natural, living language - "dimotiki" developed. It was a language which was spoken by the Greeks out of public institutions and it developed and existed independently of official language of Greek State what was exactly "katharevousa". For about 150 years two antithetic linguistic ideas ("katharevousa"and "dimotiki") were in struggle for primacy and for recognition as an official language in Greek state. That contradiction which was language question ("glossiko zitima") was terminated by the Constitution of 1976 according to which "katharevousa" stopped being official language of the state and of the law. The mentioned Constitution as a main statutory act and a basis of all rights in the State was written in a language lied on "dimotiki". In these circumstances the language of law changed too. This presentation has an aim to point some demotic solutions which were used in the process of metaglossy of statutory texts. Presented here examples base on unified text of the Constitution of 1976 with its later changes and on the text of the last constitution written in "katharevousa" i.e. Constitution of 1968. Summary of presented ideas and estimation to what degree Greek language of law based on "katharevousa" differed from the present Greek language of Law, makes up the conclusion of the paper and simultaneously it will underline profile of two mentioned types of language which coexisted in the period of diglossy.
\end{abstract}

\section{Wstęp}

Prawo, jak każda nauka, stosuje język do opisu świata z danej perspektywy. Oczywiście sposób tego opisu dla każdej nauki jest zróżnicowany. W prawie stosuje się „terminologię prawa (prawną i prawniczą) będącą szczególnym rodzajem języka specjalistycznego wewnątrz języka narodowego" ". Sprawia to, że język, w jakim zostały sporządzone np. akty normatywne, różni się od powszechnie stosowanego języka narodowego i

\footnotetext{
${ }^{1}$ Pieńkos J., 1999: 8.
} 
jednocześnie sprawia, że tylko osoby znające dany kontekst, tu kontekst prawny, są w stanie właściwe zrozumieć i zinterpretować dany tekst. Taka sytuacja ma na ogół miejsce we wszystkich państwach, w których oficjalnym językiem narodowym jest jeden system językowy, a nie wiele, jak ma to miejsce np. na Cyprze czy w Kanadzie.

Grecja od początku istnienia nowożytnej państwowości była i jest państwem, w którym językiem oficjalnym był tylko jeden system językowy, powszechnie nazywany językiem greckim, usankcjonowanym zazwyczaj albo poprzez specjalny zapis w kolejnych konstytucjach albo poprzez domniemanie, że język, w jakim została zapisana ustawa zasadnicza jest językiem wzorcowym. Język ten, uznawany za oficjalny, różnił się jednak od powszechnie wykorzystywanego przez ogół społeczeństwa naturalnie rozwiniętego języka greckiego.

Niniejszy artykuł ma na celu przedstawienie sytuacji zjawiska dyglosji w greckim języku prawa, który, jak wskażę poniżej, był chronologicznie ostatnią sferą do której wkroczył ogólnie znany i wykorzystywany język demotyczny. Zjawisko to odegrało istotną rolę w kształtowaniu się greckiej rzeczywistości prawnej, ponieważ przez blisko 150 lat znajomość prawa była umiejętnością zarezerwowaną dla niewielkiej grupy społeczeństwa greckiego z dwu przyczyn:

1. Trudność poznania i zrozumienia języka prawa wynikająca ze stosowania innego systemu językowego do zapisania go : „kathatarevousa”.

2. Trudność poznania i zrozumienia języka prawa wynikająca $\mathrm{z}$ jego specyfiki $w$ ogóle.

Bez wątpienia dwa wymienione powyżej czynniki wpłynęły na grecką rzeczywistość nie tylko prawna, ale administracyjną czy społeczną, przez co, jak twierdzi Tseronis ${ }^{2}$, niektóre pokolenia Greków nadal nie wiedzą, jak wyrażać się w sferach życia regulowanych przez władzę państwową.

\section{Dyglosja w języku greckim}

Język grecki uważany jest za jeden z najstarszych języków świata. Według badaczy zachował on ciągłość od swoich początków aż po dzień dzisiejszy, co sprawia, że liczy on sobie ponad 3000 lat, a istnieją też opinie, że nawet więcej ${ }^{3}$. Podczas tak długiego okresu język grecki ewoluował, na skutek czego jego obecna forma mimo ciagłości nie jest identyczna z pierwotną. Osoby, które posługiwały się językiem greckim przez kilka tysiącleci, czyli od początku istnienia greckiej świadomości wspólnoty kulturowej, religijnej, politycznej i językowej, były przyzwyczajone do istnienia dyglosji w języku greckim, która, jak twierdzą Browning ${ }^{4}$ i Tseroukis ${ }^{5}$, została wyraźnie odnotowana $\mathrm{w}$ tekstach pisanych już około I w p.n.e.

Dyglosja $\mathrm{w}$ historii języka greckiego to według Fragkoudaki ${ }^{6}$ fenomen na skale światowa, ponieważ $\mathrm{w}$ języku greckim dyglosja polega na jednoczesnym istnieniu $\mathrm{w}$ społeczeństwie dwu systemów językowych, które pochodzą z tego samego źródła, ze starożytnej greki. Za Davidem Crystalem ${ }^{7}$ sytuację tę należy uznać za tzw. low variety. Tymczasem dyglosja, która jest częstszym zjawiskiem na świecie, polega na jednoczesnym istnieniu dwu języków narodowych (np. Kanada), kiedy to mówimy o high variety.

\footnotetext{
${ }^{2}$ Tseronis A. 2002: 12 .

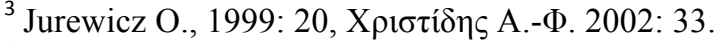

${ }^{4}$ Browning R. 1972: 43.

${ }^{5}$ Tseronis A. 2002: 3.

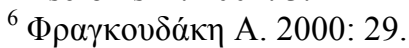

${ }^{7}$ Crystal D. 2008: 121.
} 
Istnienie dyglosji opartej na tym samym źródle w Grecji było rezultatem poszukiwań wspólnego języka, który oprócz wspólnej administracji mógłby zjednoczyć ludzi nazywających się Hellenami. Taka koncepcja pojawiła się już w epoce Aleksandra Wielkiego, trwała w okresie Cesarstwa Bizantyńskiego i była obecna przez około 150 lat jako stały element życia społecznego, kulturalnego i politycznego nowożytnego państwa greckiego ${ }^{8}$. Szczególnie w tym ostatnim okresie, czyli w latach 1830-1975 dyglosja odegrała istotną rolę w życiu społecznym Greków.

Wraz z zainicjowaniem walk o wyzwolenie Grecji spod okupacji tureckiej i włoskiej greccy powstańcy zaczęli zadawać sobie pytania o przyszłość swojej ojczyzny, w tym o język, jakim będą mówić. Problemem, przed jaki stanęli obywatele nowożytnego państwa greckiego, było znalezienie lingua franca, która byłaby zrozumiała dla mieszkańców wszystkich części Grecji, posługujących się w tym czasie różnymi dialektami ${ }^{9}$. Dyskusję nad formą przyszłego oficjalnego języka greckiego rozpoczęli filolodzy, literaci, politycy, a nawet niepiśmienni partyzanci. Na te czasy, czyli na przełom XVII i XVIII wieku datuje się początki tzw. kwestii językowej ${ }^{10}$, czyli debaty nad formą wspólnego języka greckiego, która z czasem nasiliła się między dwoma głównymi środowiskami:

3. zwolennikami ożywienia starożytnego języka greckiego,

4. zwolennikami języka naturalnego - ludowego.

Mimo iż w ustawie o edukacji z 1834 roku pojawił się zapis mówiący o tym, że oficjalnym językiem szkolnictwa w Grecji jest starożytna Greka ${ }^{11}$, to nie można jednoznacznie stwierdzić, iż zwyciężyli zwolennicy tego systemu językowego. Konstytucja Grecji, jak i inne akty prawne były bowiem sporządzone w sztucznym

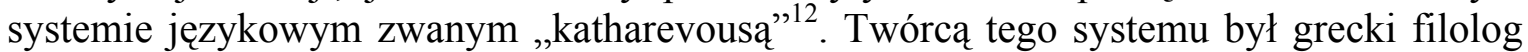
Adamantios Korais, który poszukiwał rozwiązania mogącego usatysfakcjonować zarówno zwolenników martwej klasycznej greki, jak i żywego języka demotycznego. Jego idea oczyszczenia języka (gr. $\kappa \alpha \theta \alpha \rho i \zeta \zeta \omega-$ oczyszczam) polegała na usunięciu z języka wszystkich zapożyczeń i naleciałości, które nie miały antycznego greckiego pierwowzoru oraz zastapienie ich neologizmami wzorowanymi na języku starożytnym. Tego typu zmiany miały zachodzić $\mathrm{w}$ zakresie morfologii, składni i leksyki ${ }^{13}$, niestety ogólna idea archaizowania i poprawiania języka na wzór dialektu attyckiego, koine nowotestamentowej, czy też koine bizantyńskiej nie została usystematyzowana i nie doczekała się opracowania gramatycznego ${ }^{14}$, co dawało dużo swobody $\mathrm{w}$ formowaniu wypowiedzi użytkownikom tego języka. W efekcie powstała swego rodzaju hybryda językowa, której naczelną zasadą była archaizacja języka. Taki właśnie system językowy był oficjalnym językiem Grecji aż do roku 1975, kiedy to przestały obowiązywać zawarte w dotychczasowych konstytucjach zapisy mówiące o tym, iż „katharevousa” jest oficjalnym językiem państwa greckiego, którym posługiwano się w administracji, szkolnictwie i polityce.

Przez okres 1830-1975 w życiu codziennym i prywatnym Grecy posługiwali się językiem, jaki wykształcił się na przestrzeni wieków w sposób naturalny. Był to system językowy, bazujący na tradycji językowej - języku ludowym z okresu cesarstwa bizantyńskiego, który również $\mathrm{w}$ tamtych czasach nie był oficjalnym językiem

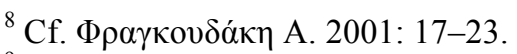

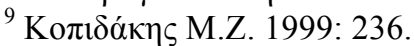

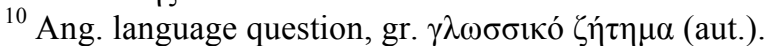

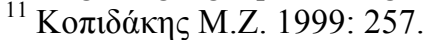

12 Język oczyszczony (aut.).

${ }^{13}$ Horrocks G. 2006: 618.

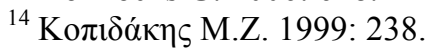


administracji państwowej. Język ten to „dimotiki”, czyli język ludowy ${ }^{15}$. Od początku swego istnienia nie doczekał się on nie tylko systematycznego, ale żadnego opracowania gramatycznego czy leksykalnego. Przez greckie elity społeczne i intelektualne uważany był on za język „niski"16 i niebędący w stanie sprostać wymaganiom nowożytnej administracji państwowej. Jednocześnie był to system językowy, który mimo różnic dialektalnych był zrozumiały dla wszystkich mieszkańców Grecji.

W sytuacji, kiedy obywatele nowożytnego państwa greckiego posługiwali się dwoma systemami językowymi: 1 . wyuczonym w szkole niczym język obcy językiem oficjalnym i 2. codziennym, powszechnym i naturalnie wykształconym naturalnym zjawiskiem był dyglosja. Kolejne konstytucje greckie utrzymywały ten stan mimo coraz bardziej liberalnych zapisów w konstytucji na temat oficjalnego języka greckiego ${ }^{17}$. Dzięki ustawom wprowadzającym „dimotiki” do szkół podstawowych, a potem i średnich język

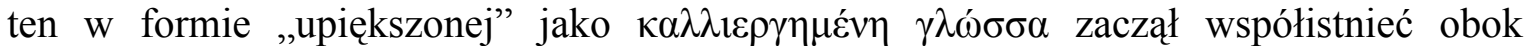
„katharevousy” zarezerwowanej z biegiem czasu tylko dla administracji państwowej i prawa $^{18}$. Ostateczne rozwiązanie kwestii językowej przyniosły dopiero akty normatywne regulujące status i formę języka, co miało miejsce od roku 1975.

\section{Język grecki regulowany prawem i grecki język prawa}

Ostatnim obszarem, gdzie „dimotiki” była niedopuszczalna, była legislacja. Mimo prawnej ochrony przed zmianami systemu językowego w latach 60. XX wieku filolodzy związani z Manolisem Triantafyllidisem i stworzonym przez niego Instytutem Studiów Nowogreckich na Uniwersytecie w Salonikach podjęli się pracy metaglosji - tłumaczenia wewnątrzjęzykowego tekstów prawnych tworzonych w „katharevousie” na język demotyczny. Czołową postacią tego ruchu był Christoforos Christidis, który jako prawnik postulował, aby teksty prawne (w szczególności akty prawne) były jasne, zrozumiałe i zapisane żywym językiem ${ }^{19}$. Twierdził on, że szczególnie prawo, które dotyczy wszystkich obywateli danego państwa, musi być dla nich zrozumiałe. W roku 1963 opublikował on tekst Kodeksu cywilnego Grecji, który przetłumaczył na język demotyczny. Jego celem było nie tylko udowodnienie, że „dimotiki” jest na tyle żywym i elastycznym językiem, w którym można zapisać nawet akty prawne, ale również pokonanie lęku, iż „dimotiki” daje zbyt dużą swobodę w kreowaniu wypowiedzi, co może doprowadzić do niezrozumienia ${ }^{20}$.

Ostatecznie w roku 1975, kiedy to opublikowano obowiązującą do dziś w Grecji wraz z późniejszymi zmianami konstytucję, „dimotiki” stała się podstawą dla języka nie tylko Greków, ale i państwa greckiego wraz z administracją i sądownictwem. Jak twierdzi Stavrakis, fakt utraty przez „katharevousę” statusu oficjalnego języka Grecji nastąpił poprzez brak zapisu, który ustalałby taki status w konstytucji z roku 1975, czyli przez domniemanie braku nakazu stosowania „katharevousy” zaczęto stosować język powszechnie używany przez Greków również w sferze legislacji i administracji państwowej $^{21}$. Kolejnym krokiem mającym na celu rozwiązanie kwestii językowej i oczywiste ustalenie oficjalnego języka Grecji była ustawa o numerze N309/76 z roku 1976, której artykuł 2. wprowadzał język nowogrecki do szkolnictwa wszystkich szczebli,

\footnotetext{
${ }^{15}$ Jurewicz O. 1999: 27-28.

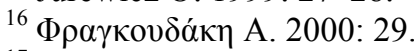

${ }^{17}$ Gortych K. 2007: 114-117, 123-126.

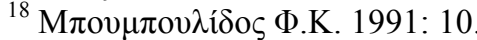

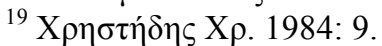

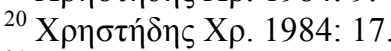

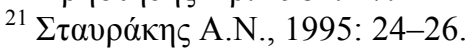


w tym do szkolnictwa wyższego. Jako język nowogrecki uznano „, (..) $\eta \delta 1 \alpha \mu \rho \rho \varphi \omega \theta \varepsilon i ́ \sigma \alpha$

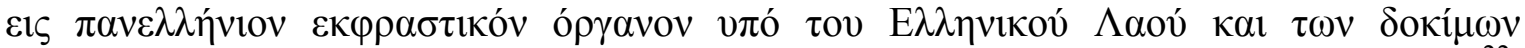

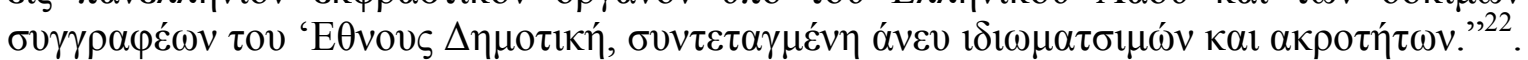
Ostatecznie kwestię językową rozwiązała ustawa o numerze N1228/1982, wprowadzająca system monotoniczny oraz ustawa o numerze N1406/83 z roku 1983, na mocy której język demotyczny stał się językiem sądów, orzeczeń sądowych, nakazów i wszelkich dokumentów sporządzanych przez organy władzy sądowniczej.

Współczesny język grecki, w jakim sporządza się lub powinno sporządzać się teksty prawne i prawnicze, jest jednak nadal przedmiotem prawników, czego dowodem jest istnienie sporu skrajnych opinii na temat tego, czy w ogóle istnieje: Liappis a priori zakłada istnienia takiego języka i twierdzi, że używanie języka powszechnego jest niemożliwe w sferze prawa ${ }^{23}$, tymczasem Stavrakis jest zdania, że grecki język prawa w ogóle nie istnieje i na potrzeby prawa powinno się wykorzystywać pisemną wersję języka życia akademickiego i naukowego jako wzorcowych ${ }^{24}$. Językiem tym jest język demotyczny, ale coraz częściej dostrzega się w nim obecność pewnych elementów „katharevousy”, co potwierdzają kolejni badacze: Liakos ${ }^{25}$, Mackridge ${ }^{26}$, Holton,

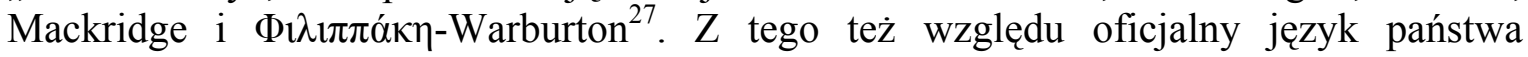
greckiego coraz częściej nazywany jest Wspólnym Językiem Nowogreckim - NEK

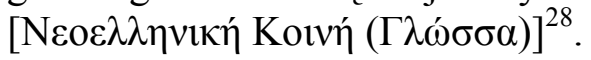

\section{Porównanie „katharevousy" i ,dimotiki” w aktach normatywnych (Konstytucja Grecji 1968 i 1975)}

Fakt, iż język prawa sprzed okresu uznania języka demotycznego za język oficjalny Grecji, w tym język prawa różnił się w znacznym stopniu od języka praw po roku 1975 a szczególnie po roku 1983 i 1983, został potwierdzony przez konieczność utworzenia komisji złożonej z prawników, filologów i językoznawców, którzy dokonaliby wg Evrytenisa przepisania (gr.: $\mu \varepsilon \tau \alpha \gamma \rho \alpha \varphi \eta)^{29}$, a według Stavrakisa metaglosji (gr.: $\mu \varepsilon \tau \alpha \gamma \lambda \omega ́ \tau \tau \imath \sigma \eta)$ tekstów prawnych.

Poniższe porównanie służy przedstawieniu dwu problemów:

5. Wskazaniu różnic między dwoma systemami językowymi: „katharevousą” i NEK.

6. Wskazaniu rozwiązań, jakie zastosowano podczas wyrażania treści zapisanych „katharevousą" w NEK.

Porównanie tekstów o podobnej czy nawet tej samej treści unaocznia różnice, jakie istniały między dwoma systemami językowymi. Teksty obydwu konstytucji zostały skonfrontowane pod względem trzech elementów systemu językowego: w zakresie morfologii, składni i leksyki. Celowo pomijam zapis w systemie politonicznym, jaki obowiązywał jeszcze do roku 1982, ponieważ nie miał on wpływu na system fonetyczny ani „katharevousy”, ani „dimotiki”

\footnotetext{
${ }^{22}$, ,...) przekształcony w ogólnogreckich organach tłumaczeniowych na podstawie języka narodu greckiego i uznanych pisarzy narodowych język demotyczny bez elementów dialektalnych i skrajnych form

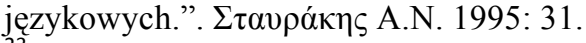

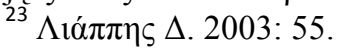

${ }^{24} \Sigma \tau \alpha$ ${ }^{2} \alpha \dot{\kappa} \eta \varsigma$ A. 1995: 75-78.

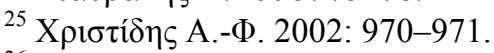

${ }^{26}$ Mackridge P. 2004: 54-55.

${ }^{27}$ Holton D. $\mathrm{i}$ in.: 2006: XV-XVI.

${ }^{28}$ Skrót za: Mackridge P. 2004: 36.

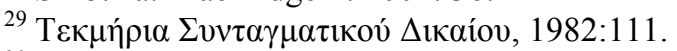

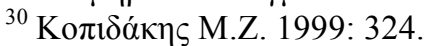


wymawiane tak samo, pomijano też w wymowie w ogóle przydech. W trakcie porównania wskazuję również cechy archaizujące i martwe „katharevousy” w porównaniu do języka demotycznego, którym Grecy posługiwali się na co dzień w okresie dyglosji. Przytoczone przykłady i zagadnienia wskazują tylko najistotniejsze różnice między dwoma systemami językowymi. Każdy akt normatywny poddany thumaczeniu wewnątrzjęzykowemu może zawierać kolejne rozwiązania zastosowane w procesie metaglosji.

Tabela 1. Porównanie morfologii

\begin{tabular}{|c|c|}
\hline Konstytucja z roku $1968^{31}$ & $\begin{array}{c}\text { Konstytucja z roku } 1975 \text { z późniejszymi } \\
\text { zmianami }^{32}\end{array}$ \\
\hline $\begin{array}{l}\Sigma v ́ v \tau \alpha \gamma \mu \alpha \tau \eta \eta_{\delta} E \lambda \lambda \alpha^{\prime} \delta \varsigma^{33} \\
\text { Genetivus singularis wg klasycznej III } \\
\text { deklinacji (spółgłoskowej). }\end{array}$ & $\begin{array}{l}\Sigma v ́ v \tau \alpha \gamma \mu \alpha \tau \eta \underline{\mathrm{E} \lambda \lambda \alpha \dot{\alpha} \delta \varsigma \varsigma} \\
\text { Genetivus singularis. }\end{array}$ \\
\hline 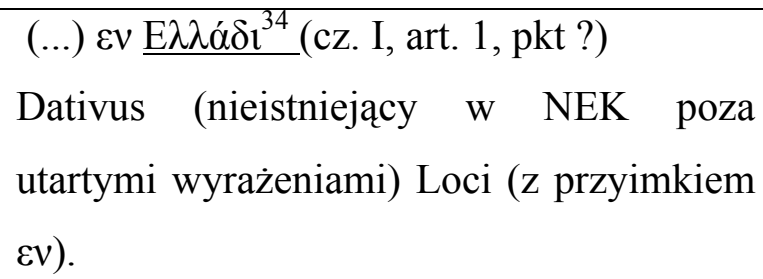 & $\begin{array}{l}(\ldots) \sigma \tau \eta \nu \text { E } \lambda \lambda \alpha \dot{\alpha} \delta \alpha(\text { cz. I, art. } 3 \text { pkt 1) } \\
\text { Accusativus Loci (z przyimkiem } \sigma \varepsilon) .\end{array}$ \\
\hline 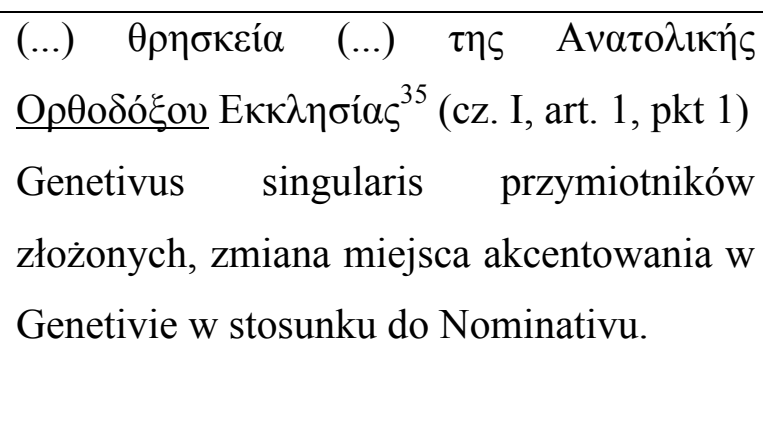 & 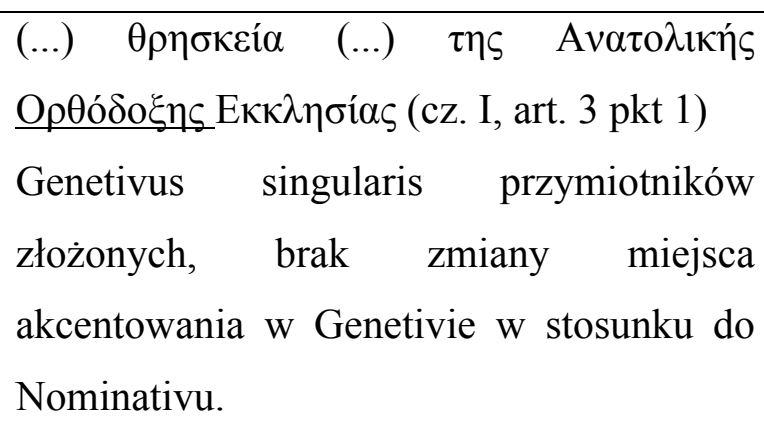 \\
\hline 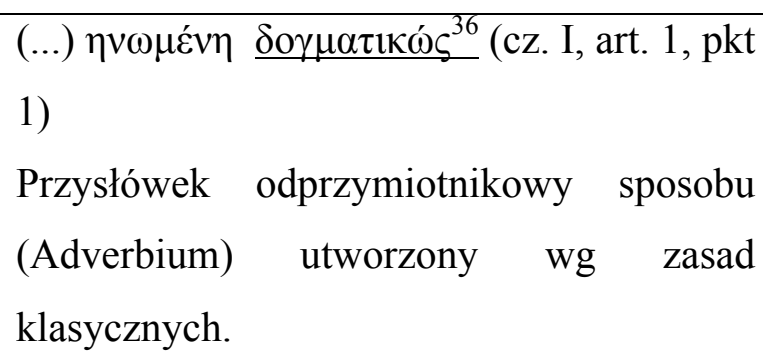 & $\begin{array}{l}\text { Przysłówek odprzymiotnikowy sposobu } \\
\text { (Adverbium) wzorowany na „dimotiki”. }\end{array}$ \\
\hline 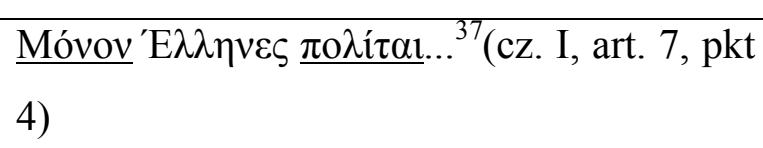 & 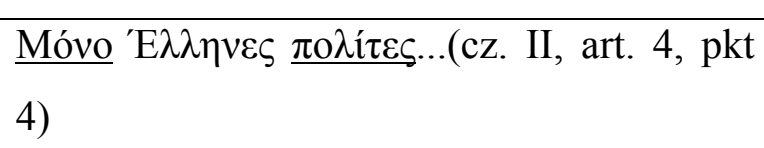 \\
\hline
\end{tabular}

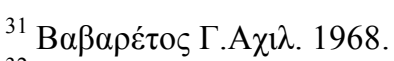

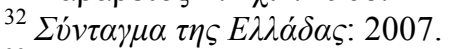

${ }^{33}$ Treść przekładu identyczna dla obydwu kolumn również dla kolejnych przykładów podawany jednorazowo. Tu: Konstytucja Grecji (aut.).

${ }^{34}$ (...) $w$ Grecji (aut.).

${ }^{35}$ ( ...) religia (...) Wschodniego Kościoła Ortodoksyjnego (aut.).

${ }^{36}$ (...) [kościół] związany dogmatycznie (aut.).
} 


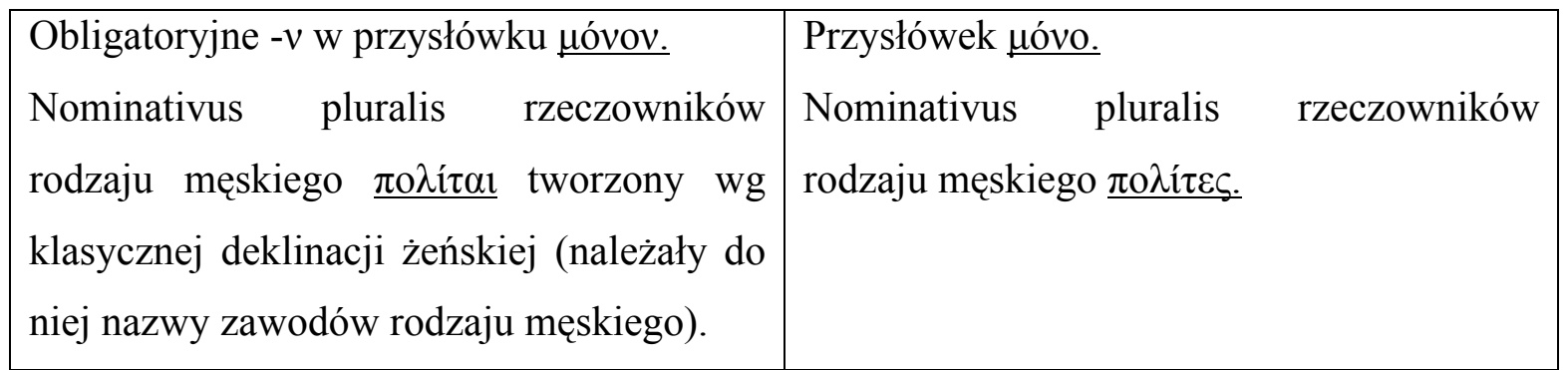

Tabela 2. Porównanie składni

\begin{tabular}{|c|c|}
\hline Konstytucja z roku $1968^{38}$ & $\begin{array}{c}\text { Konstytucja z roku } 1975 \text { z późniejszymi } \\
\text { zmianami }^{39}\end{array}$ \\
\hline 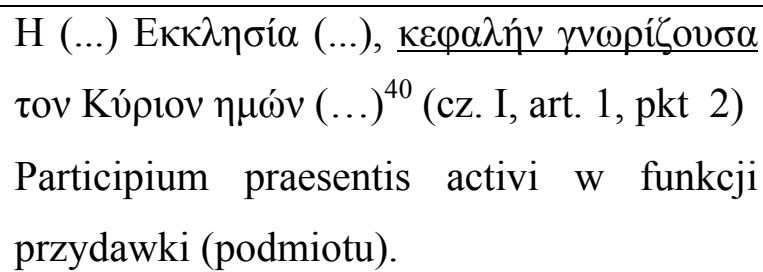 & 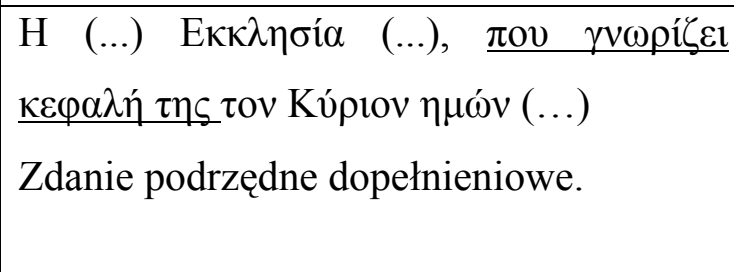 \\
\hline 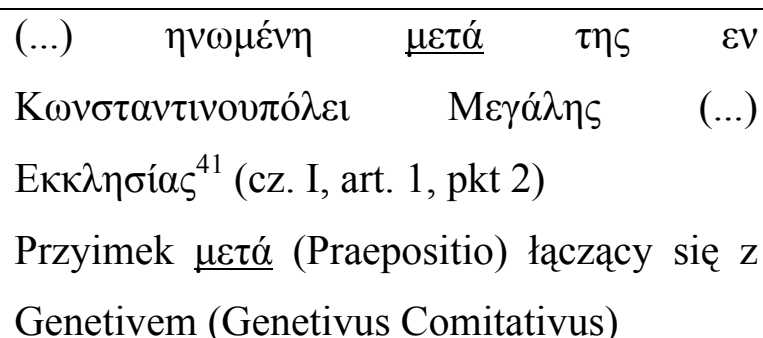 & 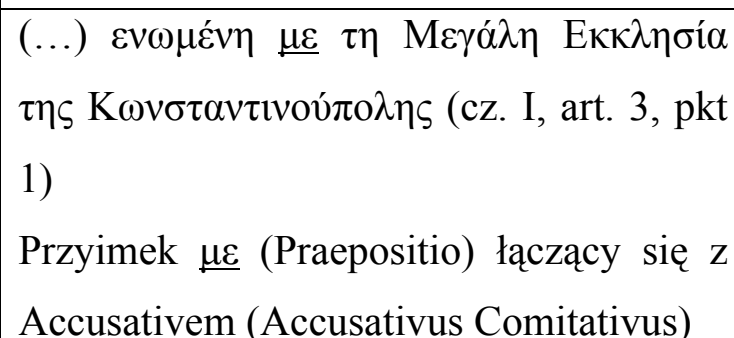 \\
\hline 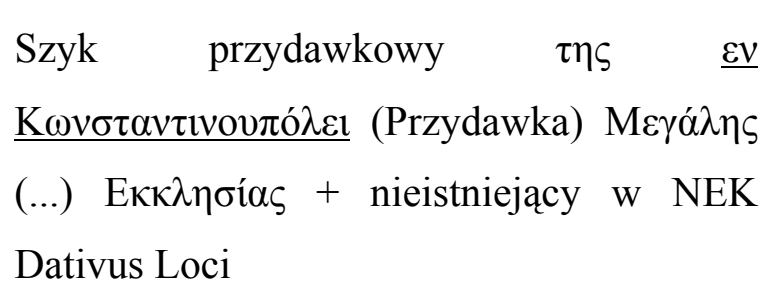 & 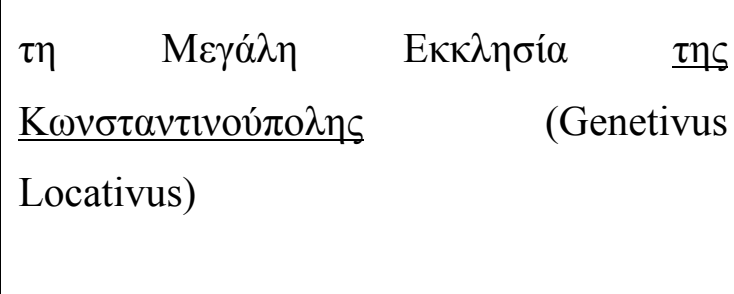 \\
\hline 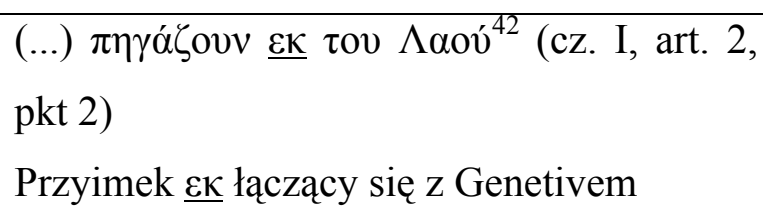 & 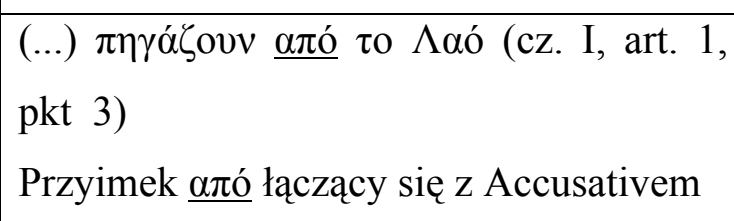 \\
\hline 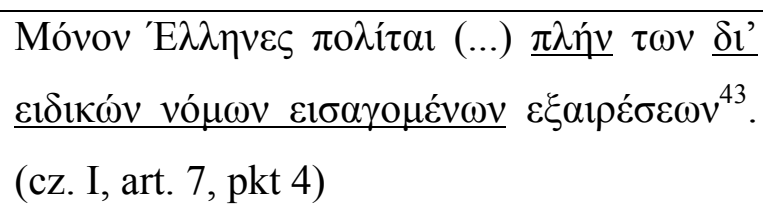 & 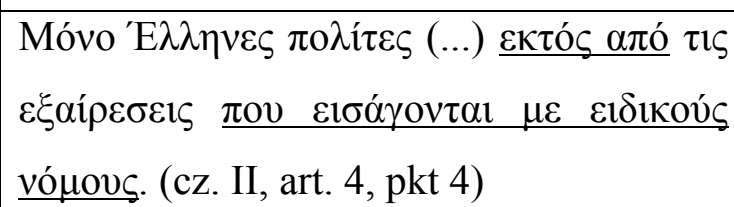 \\
\hline
\end{tabular}

\footnotetext{
${ }^{37}$ Tylko obywatele greccy(...) (aut.).

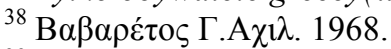

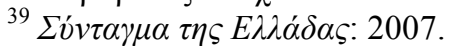

${ }^{40}$ Kościół uznający Pana naszego [Jezusa Chrystusa] za głowę kościoła (...) (aut.).

${ }^{41}$ [Kościót] zjednoczony z Wielkim Kościołem w Konstantynopolu (aut.).

42 (...) wywodza się z Ludu (aut.).

${ }^{43}$ Tylko obywatele greccy (...) poza wyłaczeniami, jakie wprowadzaja ustawy szczególne (aut.).
} 


\begin{tabular}{|c|c|}
\hline 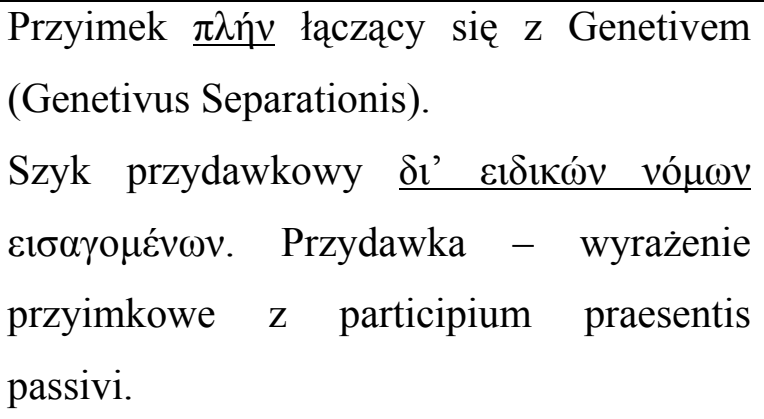 & 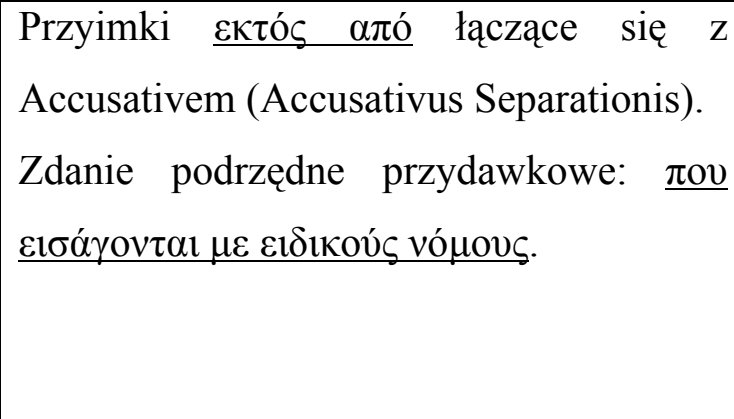 \\
\hline 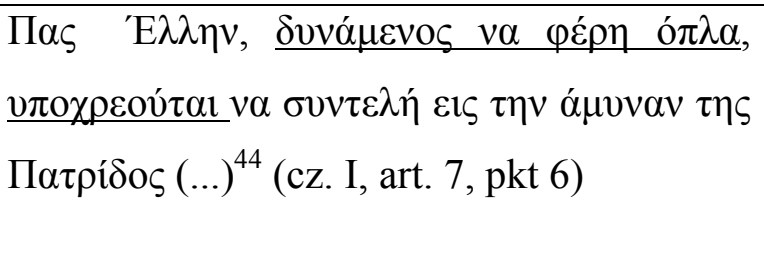 & 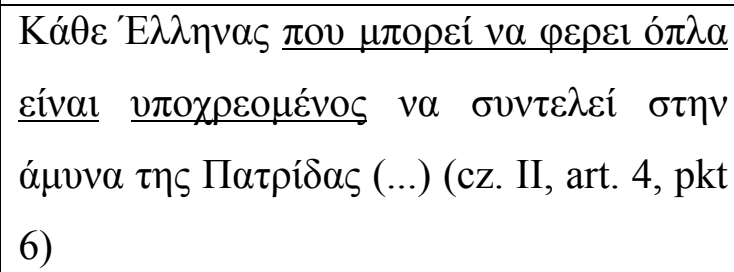 \\
\hline 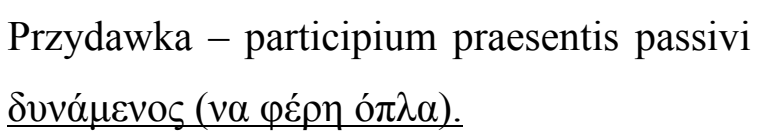 & 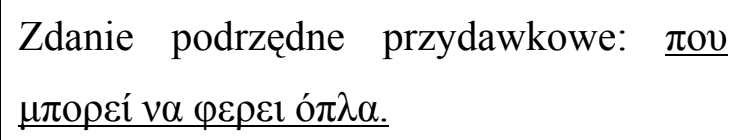 \\
\hline $\begin{array}{l}3 \text { persona singularis indicativi praesentis } \\
\text { passivi } \underline{0 \pi 0} \chi \rho \varepsilon \text { ev́ } \tau \alpha \mathrm{l} \text {. }\end{array}$ & 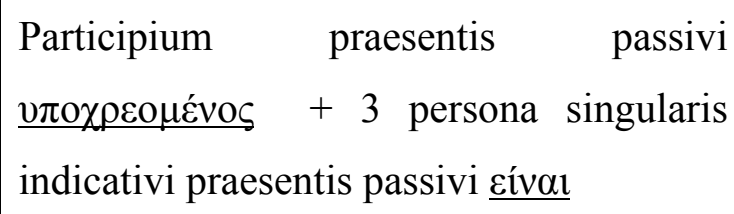 \\
\hline 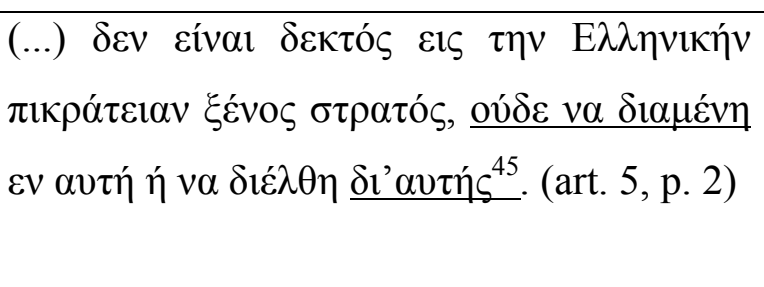 & 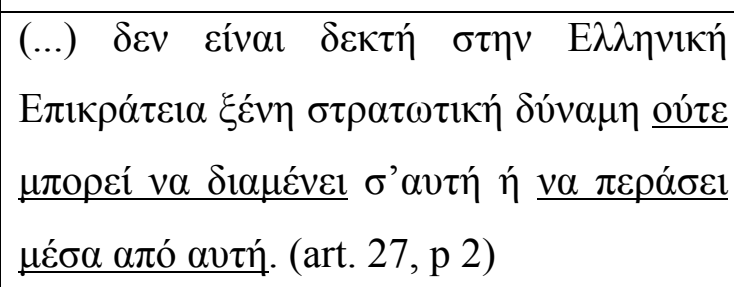 \\
\hline $\begin{array}{l}\text { Po partykule: } \underline{\text { ov́} \delta \varepsilon} \text { brak czasownika } \\
\text { modalnego, jest tylko coniunctivus: } \underline{v \alpha} \\
\underline{\delta \alpha \mu \varepsilon \varepsilon v \eta .}\end{array}$ & 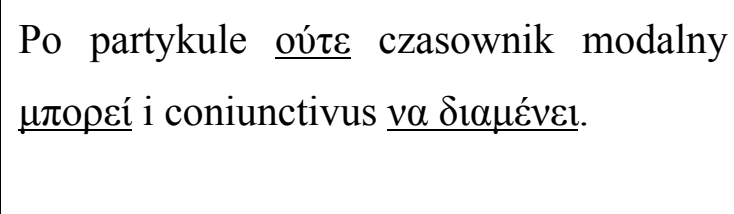 \\
\hline & 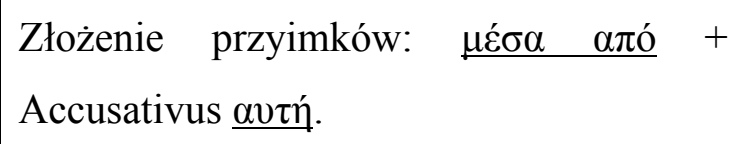 \\
\hline
\end{tabular}

Tabela 3. Porównanie leksyki

\begin{tabular}{|c|c|}
\hline Konstytucja z roku $1968^{46}$ & $\begin{array}{c}\text { Konstytucja z roku } 1975 \text { z późniejszymi } \\
\text { zmianami }^{47}\end{array}$ \\
\hline 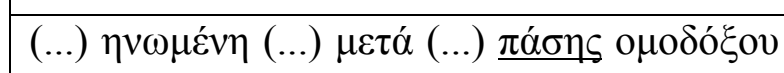 & 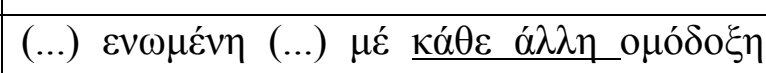 \\
\hline
\end{tabular}

\footnotetext{
${ }^{44}$ Każdy Grek, zdolny do noszenia broni, jest obowiazany do uczestniczenia w obronie Ojczyzny (...) (aut.).

${ }^{45}$ (...) żadne obce wojska na terytorium Grecji nie moga ani stacjonować ani przemieszczać się w jego granicach (aut.).

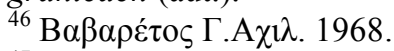

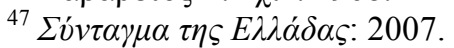




\begin{tabular}{|c|c|}
\hline 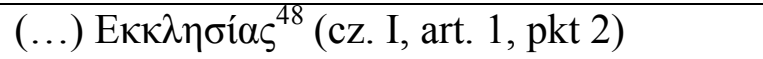 & 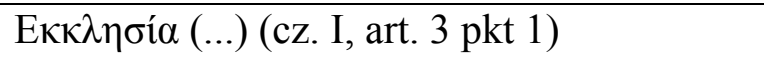 \\
\hline 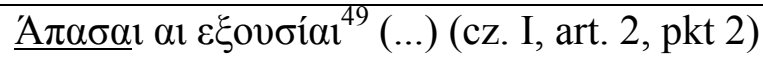 & 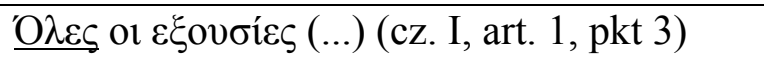 \\
\hline 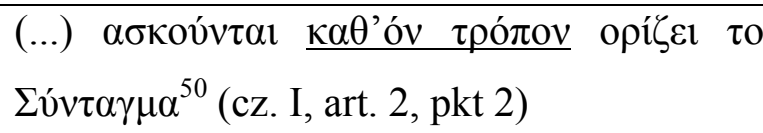 & 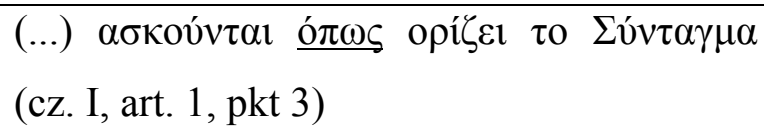 \\
\hline 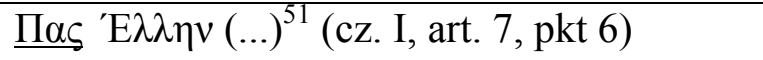 & $\underline{\mathrm{K} \alpha \dot{\theta} \theta \varepsilon}{ }^{\prime} \mathrm{E} \lambda \lambda \eta v \alpha \varsigma$ (...) (cz. II, art. 4, pkt 6) \\
\hline 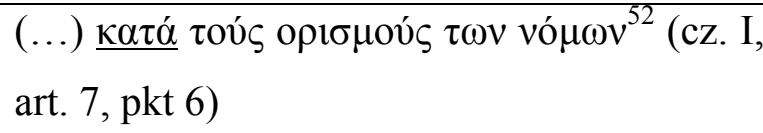 & 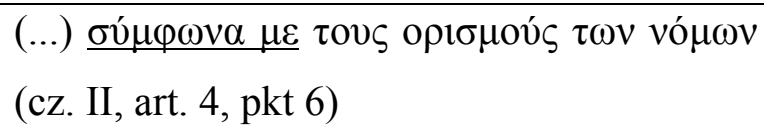 \\
\hline 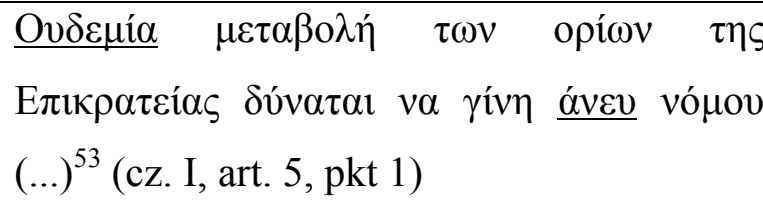 & 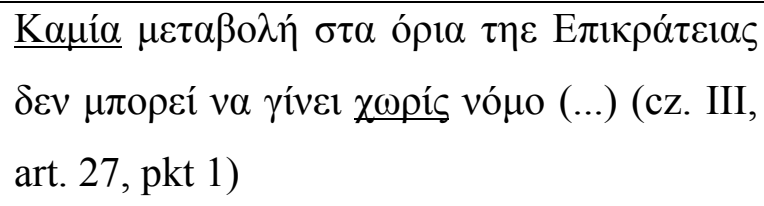 \\
\hline 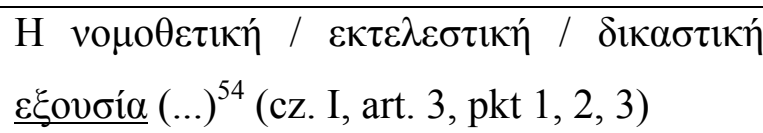 & 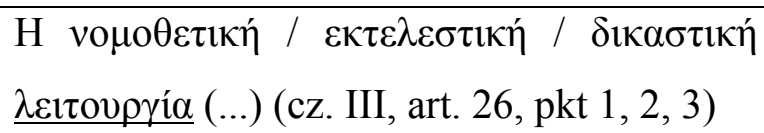 \\
\hline
\end{tabular}

\section{Podsumowanie}

Wskazane powyżej różnice między systemami językowymi: „katharevousa” i NEK, jakie są widoczne w tekstach o tej samej treści, prowadzą do kilku wniosków:

1. Tekst zapisany w „katharevousie” zawiera takie elementy języka, które nie przetrwały w języku demotycznym od czasów starożytnych:

a) Morfologia: Dativus, fleksja wzorowana na klasycznych zasadach gramatycznych wraz z zasadami akcentowania, formy istniejące już tylko w grece starożytnej,

b) Składnia: archaiczne przyimki, które tworzą wyrażenia przyimkowe według zasad starożytnych ( $\mu \varepsilon \tau \alpha \dot{\alpha}, \varepsilon \kappa, \varepsilon v$ ), przydawka wyrażona participium zamiast zdania podrzędnego przydawkowego, rzadki szyk przydawkowy,

c) Leksyka: słownictwo nieistniejące w języku demotycznym od czasów średniowiecznych. Elementy te można uznać w większości za martwe - nie przetrwały nawet $\mathrm{w}$ oficjalnym języku prawa, a przynajmniej nietakiej funkcji semantycznej, jaką miały w „katharevousie”.

2. Tekst zapisany w ,katharevousie” jest mniej zrozumiały ze względu na szyk części zdania, stosowanie leksyki bazującej na języku starożytnym i średniowiecznym oraz archaizowaną morfologię.

Fakt trudności w zrozumieniu tekstu wymuszał na osobach korzystających z prawa również w życiu zawodowym znajomość choćby w stopniu podstawowym starożytnej greki lub nauki „katharevousy”, co miało miejsce jeszcze długo po roku 1976, kiedy to rozpoczęto prace translacyjne wewnątrz języka nowogreckiego, czyli metaglosję.

\footnotetext{
48 (...) [Kościót grecki] jest zjednoczony ze wszystkimi kościołami uznającymi te same dogmaty(...) (aut.).

49 Wszystkie władze (aut.).

${ }^{50}$ (...) są sprawowane w sposób, jaki określa Konstytucja (aut.).

${ }^{51}$ Każdy Grek (...) (aut.).

${ }^{52}$ (...) zgodnie z postanowieniami ustaw (aut.).

53 Żadna zmiana granic Państwa nie może być dokonana bez odpowiedniej ustawy (...) (aut.).

${ }^{54}$ Władza ustawodawcza / wykonawcza / sądownicza (...) (aut).
} 
Istniejąca w języku greckim dyglosja sprawiła, że osoby mniej wykształcone nie były w stanie nie tylko samodzielnie, ale nawet z pomocą prawników właściwie zrozumieć literę prawa. Wynikało to $\mathrm{z}$ faktu, iż przed rokiem 1967 język demotyczny stopniowo wkraczał do szkół podstawowych i średnich nie tylko jako język nauczania, ale i jako język podręczników, lektur i tekstów źródłowych, o czym wspomniałam w drugiej części niniejszego artykułu. Z drugiej strony grono prawników i osób związanych z procesem legislacyjnym na skutek tradycyjnego i wieloletniego panowania „katharevousy” w życiu oficjalnym państwa greckiego sprawili, że zaistniała potrzeba podjęcia prac przygotowawczych do zapisania tekstów prawnych i prawniczych w Grecji w nowym języku ${ }^{55}$, ponieważ język demotyczny, dotąd pomijany w nauce prawa, nie dysponował ad hoc własną bogatą terminologią prawniczą, należało ją dopiero wypracować.

Wskazane przeze mnie różnice w obowiązujących przez pewien czas w Grecji systemach językowych potwierdzają słuszność metaglosji. Dzięki temu procesowi wiele aktów prawnych zmieniło swój język zapisu, w jakim obowiązują do teraz, a jednocześnie nie zmieniło treści. Akty prawne w nowej postaci z całą pewnością są zrozumiale zarówno dla prawników zajmujących się prawem Grecji, jak dla tłumaczy współczesnego języka greckiego, co sprawia, że zgodnie z ideą zwolenników języka demotycznego, przeciętny Grek jest w stanie zrozumieć ogólnie akty normatywne, a prawnik nie musi ich przekładać na język przeciętnego obywatela greckiego ${ }^{56}$.

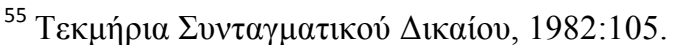

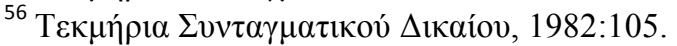




\section{Bibliografia}

Teksty źródłowe

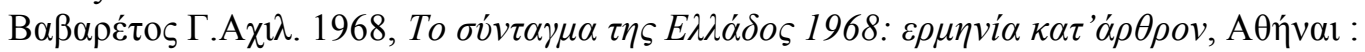

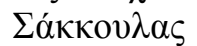

$\Sigma \dot{v} v \tau \alpha \gamma \mu \alpha \tau \eta \varsigma E \lambda \lambda \alpha \dot{\delta} \delta \varsigma$ 2007, http://www.parliament.gr/politeuma/syntagma.pdf

Literatura przedmiotu

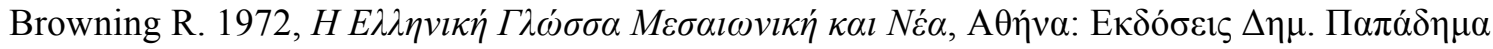

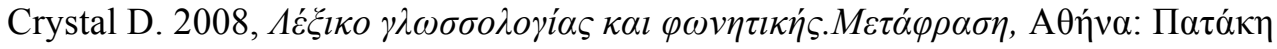

Gortych K. 2007, Retoryka polityczna XX-wiecznej Grecji. Historyczne i lingwistyczne aspekty wybranych tekstów, Rozprawa doktorska

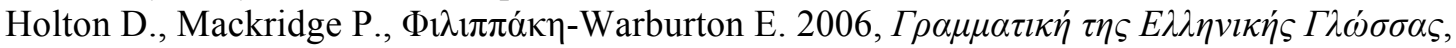

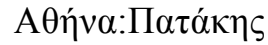

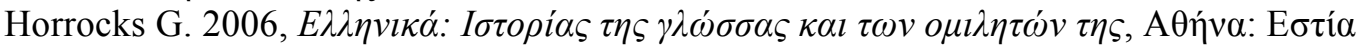

Jurewicz O. 1999, Gramatyka historyczna języka greckiego, Warszawa: Państwowe Wydawnictwo Naukowe

Jurewicz O. 1984, Historia literatury bizantyńskiej. Zarys. Wrocław: Ossolineum

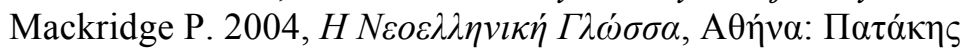

Pienkos J 1999, Podstawy juryslingwistyki. Język w prawie - prawo w języku, Warszawa: Muza S.A.

Tseronis A. 2002, Diglossical past and present in lexicographical practice: the case of two Greek dictionaries, http://www.ling.lancs.ac.uk/pubs/clsl/cls1119.pdf

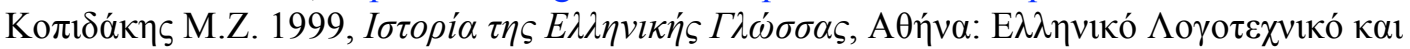

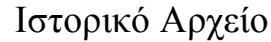

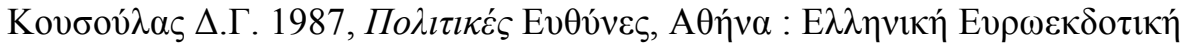

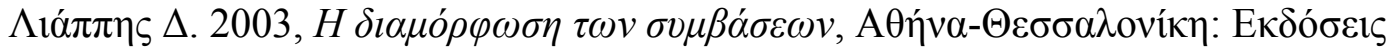
$\Sigma \alpha \kappa \kappa о v ́ \lambda \alpha$

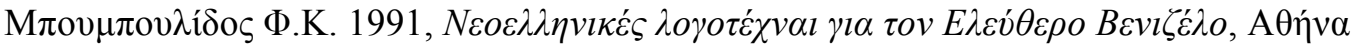

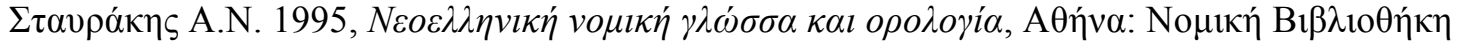

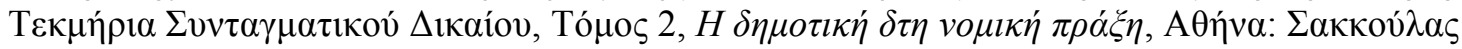

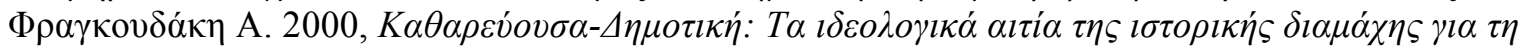

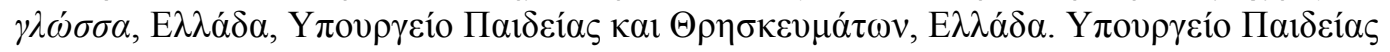

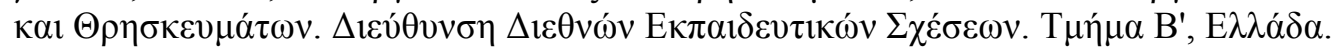

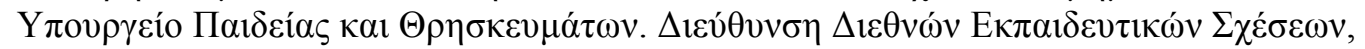

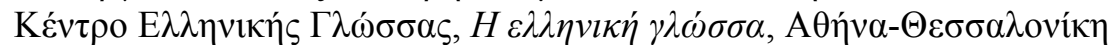

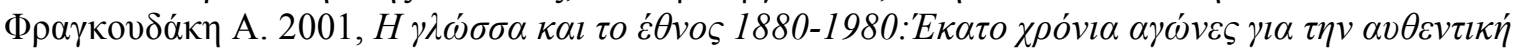

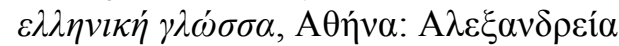

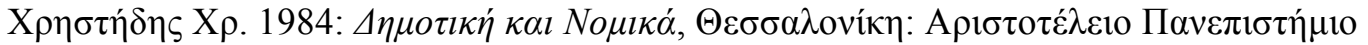

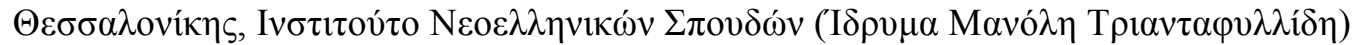

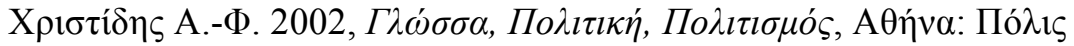

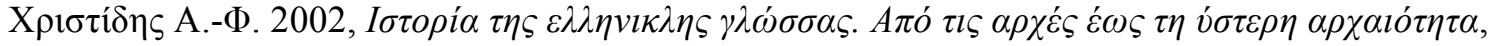

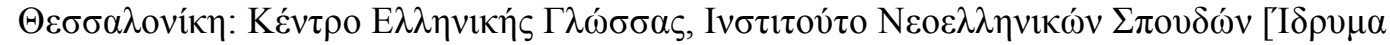

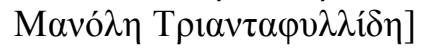

